Original Research Paper

\title{
Agriculture Production and Economic Growth
}

\author{
Chintan D. Shah \\ Lion Wealth Advisors Pvt Ltd. 106/b Synergy Tower, \\ Prahlad-Nagar Corporate Road, Ahmedabad, India-380018, India
}

Article history

Received: 16-07-2015

Revised: 03-08-2015

Accepted: 21-10-2015

Email: chintan.shah@lionwealthadvisors.com

\begin{abstract}
Post world-war II global economy is growing at steady pace and most of nations have been experiencing rise in per capita income whether they are rich or poor. Agriculture industry is major employer of poor people in low income nations where large segment of population work as an agriculture labourers. While in rich nations less than one percentage population is occupied in agriculture activity. In this article relationship between economic growth and agriculture production is evaluated for rich, middle-income and poor nations on datasets for period 1960 to 2014.
\end{abstract}

Keywords: Agriculture Production, Economic Growth, Panel Data Regression

\section{Introduction}

Agriculture industry is indispensible part of any country's economy. Agriculture industry has seen number of innovations in terms of automatic machinery and highly effective agrochemicals and pesticides. These factors have increased productivity of agriculture industry.

Agriculture policy is affected by weather, available resources and supply and demand factors for particular commodity.

As economy grows agriculture production is positively or negatively impacted. Since end of worldwar 2 due to geopolitical stability most of nations are growing at different rates. As economy grows demand for agriculture production rises or falls. It is not necessary that rise in population and economic growth has positive relationship with agriculture production as demand for agriculture products may rise but higher costs may push domestic agriculture production in decline.

The aim of paper is to understand relationship between agriculture factors and economic growth, trade for rich,-income and poor nations. This research paper intends to answer following questions:

- Is Agriculture production positively associated with GDP or not

- As nation grows and per capita increases, does it negatively affect agriculture production in terms of cost

- In which manner other factors associated with agriculture production like arable land, agriculture machinery, number of tractors etc. are affected by economic growth
To answer above three questions I have conducted empirical analysis on macroeconomic data for period 1960 to 2014. In this empirical analysis, Influence of Economic growth and international trade on agriculture factors like agriculture machinery, size of arable land, crop production etc are studied (Table 1). This analysis is done on three segments. First is for rich nations, second for middle income, third for poor nations. These countries are taken from World Bank classification (http://data.worldbank.org/about/countryand-lending-groups,2015) of countries based on per capita income. For this, five nations have been arbitrarily chosen and there datasets have been collected. On each segment panel data regression is conducted in which economic growth and international trade are independent variables and agriculture factors are dependent variable.

Table 1 for list of nations and list of agriculture factors on which effect of international trade and economic growth is studied.

In this Table 1 list of nations have been given on which empirical analysis is conducted. In last column macroeconomic factors have been mentioned which are studied. For detailed description of agriculture factors see (www.worldbank.com/indicators,2015).

\section{Literature Review}

There are number of country specific research papers which explore contribution of agriculture sector in economic growth.

Johnston and Mellor (1961) has found that agriculture sector has significant contribution in economic development for nations irrespective of their technological differences. 
Table 1. List of nations and Agriculture factors

\begin{tabular}{llll}
\hline High-income (Rich) nations & Middle-income nations & Low-income (Poor) nations & Agriculture factors \\
\hline USA & Argentina & Somalia & Agriculture machinery \\
UK & Algeria & Uganda & Agriculture land \\
Germany & India & Togo & Arable land \\
France & China & Kenya & Permanent cropland \\
Japan & Bangladesh & Agriculture tractors per 100sqkm \\
& Egypt & & Cereal production \\
& & Crop production index \\
\hline
\end{tabular}

Gollin et al. (2002) has found out that poor nations have very low per capita income compared to rich nations and agriculture productivity growth has significant impact on their economic development.

Ohkawa and Rosovsky (1960) have found that Post world war 2 period Japanese agriculture growth has contributed significantly to economic growth of nation.

Hwa (1988) has found that agriculture growth is directly linked to total factor productivity growth in economy which leads to economic growth.

Ghatak and Ingersent (1984) has written book regarding contribution of agriculture development in economic growth and how other factors have impact on agriculture development as well.

Thurlow et al (2010) has found out that under developed nations of Africa benefit from agriculture development.

This paper contributes to the existing literature in following ways.

There hasn't been any empirical analysis which explains relationship between economic growth and agriculture production. How agriculture production is affected by economic growth is studied on panel data of rich, middle income and poor nations.

\section{Data}

Datasets consists of observations for agriculture factors mentioned in Table 1 and economic growth, international trade factors. All data sets are taken from World Bank data-bank (http://data.worldbank.org/,2015) 2015. Datasets are made up of annual figures. Datasets are taken for period 1960 to 2014.

\section{Methodology}

This study examines relationship between agriculture factors and economic growth, international trade. For that purpose panel data regression has been utilized to understand relationship between these two factors. Pooled OLS panel data regression is applied on annual data for period 1960 to 2014 .

Following assumptions have been taken for applying pooled OLS regression on data.

Assumptions for pooled OLS:

- Selection of sample from cross-section is arbitrary
- There is no perfect linear relationship among explanatory variables

- Expected value of idiosyncratic error for explanatory variables in all time period is zero

- Variance of differenced errors conditional on all independent variables is constant

Following model is utilized for panel data regression:

$$
\begin{aligned}
& \log (\text { agriculture factor })=\beta_{0}+\beta_{1} \log (G D P) \\
& +\beta_{2} \log (\text { GDP per Capita }) \\
& +\beta_{3} \log (\text { imports of productsand services }) \\
& +\beta_{4} \log (\text { exports of products and services })+u
\end{aligned}
$$

$\beta_{0}=$ Intercept

$\beta_{1}=$ Coefficient of GDP

$\beta_{2}=$ Coefficient of GDP per capita

$\beta_{3}=$ Coefficient of imports of products and services

$\beta_{4}=$ Coefficient of exports of products and services

$u=$ Random error term which is normally, independently and identically distributed. It is incorporated in equation to cater for other variables

- Durbin-watson test is applied for autocorrelation detection in error terms

- Breusch-pagan test is applied for heteroscedasticity detection in error terms

- There are four independent variables and one dependent variable

- Agriculture factors mentioned in Table 1 are taken as dependent variable

\section{Results and Analysis}

Output generated by performing pooled OLS regression with help of SPSS is shown in Table 2-4. Tstatistics is utilized for checking statistical significance of coefficients. Other details are mentioned in Table 2-4.

For poor nations crop production and arable land has positive relationship with GDP. As poor nations production rises demand of crops also increases. However tractors are not in demand when GDP rises. Another important factor is that crop production has negative relationship with per capita income and exports. As per capita income rises it becomes expensive to conduct agriculture activity which pushes production lower. 
Table 2. Low-income nations in this table in first column dependent variables are written and in first row independent variables are mentioned including intercept. Results of panel data regression on low-income nations are shown in table. In parenthesis standard error is written and coefficients of independent variables are mentioned in third and fourth column. In last column number of observations, $R^{2}$ and adjusted $R^{2}$ are mentioned

\begin{tabular}{lllllll}
\hline & & & $\begin{array}{l}\text { GDP } \\
\text { Per capita } \\
\text { income }\end{array}$ & $\begin{array}{l}\text { Imports of } \\
\text { products } \\
\text { and services }\end{array}$ & $\begin{array}{l}\text { Exports of } \\
\text { products } \\
\text { and services }\end{array}$ & Other details \\
\hline Agriculture machinery & $-2.12(0.523)$ & $0.59(0.20)$ & $-1.17(0.26)$ & $0.54(0.32)$ & $-0.28(0.22)$ & $R^{2}=0.973 \bar{R}^{2}=0.972 \mathrm{~N}=275$ \\
Agriculture land & $1.684(.056)$ & $0.093(0.022)$ & $-0.027(0.029)$ & $0.174(0.035)$ & $-0.26(0.024)$ & $R^{2}=0.965 \bar{R}^{2}=0.955 \mathrm{~N}=275$ \\
Arable land & $-1.84(0.404)$ & $0.845(0.156)$ & $0.295(0.204)$ & $-1.36(0.24)$ & $0.747(0.17)$ & $R^{2}=0.815 \bar{R}^{2}=0.813 \mathrm{~N}=275$ \\
Permanent cropland & $-4.38(0.54)$ & $1.29(0.21)$ & $0.82(0.27)$ & $-2.62(0.33)$ & $1.56(0.23)$ & $R^{2}=0.793 \bar{R}^{2}=0.793 \mathrm{~N}=275$ \\
Agriculture tractors & & & & & & \\
per 100sqkm & $-1.12(0.55)$ & $-0.055(0.21)$ & $-0.75(0.27)$ & $1.2(0.33)$ & $-0.772(0.23)$ & $R^{2}=0.963 \bar{R}^{2}=0.972 \mathrm{~N}=275$ \\
Cereal production & $-2.47(0.142)$ & $1.223(0.05)$ & $-1.41(0.072)$ & $-0.37(0.08)$ & $0.43(0.06)$ & $R^{2}=0.967 \bar{R}^{2}=0.963 \mathrm{~N}=275$ \\
Crop production index & $1.17(0.10)$ & $-0.044(0.04)$ & $0.45(0.05)$ & $0.42(0.06)$ & $0.43(0.04)$ & $R^{2}=0.908 \bar{R}^{2}=0.908 \mathrm{~N}=275$ \\
\hline All coefficients are statistically significant at 5\%
\end{tabular}

All coefficients are statistically significant at $5 \%$ level using t-statistics

Heteroscedasticity and autocorrelation is not detected in error terms

Table 3. Middle-income nations in this table in first column dependent variables are written and in first row independent variables are mentioned including intercept. Results of panel data regression on middle-income nations are shown in table. In parenthesis standard error is written and coefficients of independent variables are mentioned in third and fourth column. In last column number of observations, $R^{2}$ and adjusted $R^{2}$ are mentioned

\begin{tabular}{|c|c|c|c|c|c|c|}
\hline & Intercept & GDP & $\begin{array}{l}\text { GDP } \\
\text { Per capita } \\
\text { income }\end{array}$ & $\begin{array}{l}\text { Imports of } \\
\text { products } \\
\text { and services }\end{array}$ & $\begin{array}{l}\text { Exports of } \\
\text { products } \\
\text { and services }\end{array}$ & Other details \\
\hline Agriculture machinery & $-2.8(0.21)$ & $1.0(0.05)$ & $-0.17(.03)$ & $-0.44(0.093)$ & $0.11(0.088)$ & $R^{2}=0.973 \quad \bar{R}^{2}=0.972 \mathrm{~N}=275$ \\
\hline Agriculture land & $-2.08(0.336)$ & $1.13(0.069)$ & $-0.004(.04)$ & $-0.98(0.13)$ & $0.064(0.122)$ & $R^{2}=0.965 \bar{R}^{2}=0.955 \mathrm{~N}=275$ \\
\hline Arable land & $-4.42(0.26)$ & $1.110(.053)$ & $-0.55(.036)$ & $-0.36(0.1)$ & $-0.15(0.094)$ & $R^{2}=0.815 \quad \bar{R}^{2}=0.813 \mathrm{~N}=275$ \\
\hline $\begin{array}{l}\text { Permanent cropland } \\
\text { Agriculture tractors }\end{array}$ & $-5.81(0.160)$ & $0.757(0.033)$ & $-0.538(.02)$ & $-0.147(0.06)$ & $0.037(0.058)$ & $R^{2}=0.793 \quad \bar{R}^{2}=0.793 \mathrm{~N}=275$ \\
\hline per $100 \mathrm{sqkm}$ & $0.93(0.273)$ & $-0.64(0.056)$ & $0.343(.037)$ & $0.591(0.106)$ & $0.105(0.099)$ & $R^{2}=0.963 \quad \bar{R}^{2}=0.972 \mathrm{~N}=275$ \\
\hline Cereal production & $-1.4(0.254)$ & $1.586(0.052)$ & $-0.657(.03)$ & $-0.233(0.09)$ & $-0.421(0.09)$ & $R^{2}=0.967 \bar{R}^{2}=0.963 \mathrm{~N}=275$ \\
\hline Crop production index & $-1.44(0.387)$ & $-0.049(0.079)$ & $0.049(.053)$ & $0.253(0.149)$ & $0.106(0.140)$ & $R^{2}=0.908 \quad \bar{R}^{2}=0.908 \mathrm{~N}=275$ \\
\hline
\end{tabular}

All coefficients are statistically significant at 5\% level using t-statistics

Heteroscedasticity and autocorrelation is not detected in error terms

Table 4. High-income nations in this table in first column dependent variables are written and in first row independent variables are mentioned including intercept. Results of panel data regression on high-income nations are shown in table. In parenthesis standard error is written and coefficients of independent variables are mentioned in third and fourth column. In last column number of observations, $R^{2}$ and adjusted $R^{2}$ are mentioned

\begin{tabular}{|c|c|c|c|c|c|c|}
\hline & Intercept & GDP & $\begin{array}{l}\text { GDP } \\
\text { per capita } \\
\text { income }\end{array}$ & $\begin{array}{l}\text { Imports of } \\
\text { products } \\
\text { and services }\end{array}$ & $\begin{array}{l}\text { Exports of } \\
\text { products } \\
\text { and services }\end{array}$ & Other details \\
\hline Agriculture machinery & $2.5(1.049)$ & $1.273(0.087)$ & $0.696(0.206)$ & $0.428(0.330)$ & $-1.72(0.412)$ & $R^{2}=0.973 \bar{R}^{2}=0.972 \mathrm{~N}=275$ \\
\hline Agriculture land & $2.353(.718)$ & $-0.187(0.059)$ & $0.076(0.141)$ & $1.38(0.266)$ & $-1.28(0.282)$ & $R^{2}=0.965 \bar{R}^{2}=0.955 \mathrm{~N}=275$ \\
\hline Arable land & $0.706(1.055)$ & $0.104(0.087)$ & $0.058(0.207)$ & $0.030(0.332)$ & $-0.11(0.414)$ & $R^{2}=0.815 \bar{R}^{2}=0.813 \mathrm{~N}=275$ \\
\hline Permanent cropland & $11.63(.774)$ & $-0.935(0.064)$ & $1.70(0.152)$ & $-0.15(0.244)$ & $-0.49(0.304)$ & $R^{2}=0.793 \quad \bar{R}^{2}=0.793 \mathrm{~N}=275$ \\
\hline Agriculture tractors & & & & & & \\
\hline per $100 \mathrm{sqkm}$ & $4.24(1.66)$ & $0.539(0.138)$ & $1.293(0.327)$ & $-3.4(0.523)$ & $2.26(652)$ & $R^{2}=0.963 \bar{R}^{2}=0.972 \mathrm{~N}=275$ \\
\hline Cereal production & $-0.29(1.13)$ & $0.80(0.084)$ & $-0.856(0.224)$ & $2.770(.358)$ & $-2.62(0.44)$ & $R^{2}=0.967 \bar{R}^{2}=0.963 \mathrm{~N}=275$ \\
\hline Crop production index & $1.19(.529)$ & $0.087(0.044)$ & $0.109(0.104)$ & $-0.33(0.167)$ & $0.31(0.208)$ & $R^{2}=0.908 \bar{R}^{2}=0.908 \mathrm{~N}=275$ \\
\hline
\end{tabular}

All coefficients are statistically significant at $5 \%$ level using t-statistics

Heteroscedasticity and autocorrelation is not detected in error terms

For middle income nations cereal production increases by $1.2 \%$ for $1 \%$ rise in GDP. Arable land also increases by $1 \%$ for $1 \%$ rise in GDP. Same as poor nations increased costs due to rise in per capita income pushes production lower. Rise in exports hurt agriculture production capacity in this segment as well. 
For rich nations results are same as poor nations and middle income nations. There is not major rise in arable land with rise in GDP unlike poor nations.

If we compare these three segments then except difference in percentage impact we conclude that all nations have same pattern of economic growth and agriculture production relationship.

\section{Conclusion}

In this article panel data regression was conducted for period 1960 to 2014 on agriculture factors and economic growth, international trade for rich, middle income and poor nations.

Article's main aim was to understand relationship between agriculture factors and international trade, economic growth.

After conducting empirical analysis I conclude following facts:

- Crop production, arable land, agriculture machinery usage have positive relationship with GDP for all nations irrespective of per capita income

- As nation becomes rich and per capita income rises it negatively impacts agriculture production due to higher costs

- Exports have negative relationship with agriculture production as higher exports increase currency value of nation and make it overall expensive to conduct agriculture activity

- Despite technological differences in rich and poor nations, agriculture production and economic growth has similar relationship for all nations

\section{Acknowledgement}

Author declares that there is no financial or competing interest.

\section{Funding Information}

Author is affiliated to Lion Wealth Advisors Pvt ltd, India. All the costs and resources utilized for conducting this research are financed by above mentioned company.

\section{Ethics}

This article is original and unpublished. Corresponding author has read and approved manuscript and no unethical issues are involved.

\section{References}

Ohkawa, K. and H. Rosovsky, 1960. The role of agriculture in modern Japanese economic development. Econom. Develop. Cultural Change, 9: 43-67.

Hwa, E., 1988. The contribution of agriculture to economic growth: Some empirical evidence. Am. J. Agric. Econom., 82: 1059-1074.

Johnston, B. and J.W. Mellor, 1961. The role of agriculture in economic development. Am. Econom. Rev., 51: 566-593.

Gollin, D., S. Parente and R. Richard, 2002. Role of agriculture in development. Am. Econom. Rev., 92: 160-164.

Ghatak, S. and K. Ingersent, 1984. Agriculture and Economic Development. 1st Edn., Johns Hopkins University Press, pp: 380.

Thurlow, J., P. Hazell and X. DIao, 2010. The role of agriculture in African development. World Develop., 38: 1375-1383.

DOI: 10.1016/j.worlddev.2009.06.011 